\title{
DIVERSITY AND GENETIC STRUCTURE IN NATURAL POPULATIONS OF Hancornia speciosa var. speciosa GOMES IN NORTHEASTERN BRAZIL ${ }^{1}$
}

\author{
GEORGIA VILELA MARTINS², LUIZA SUELY SEMEN MARTINS 3 , \\ ELIZABETH ANN VEASEY ${ }^{4}$, ILDO ELIEZER LEDERMAN ${ }^{5}$, EDSON FERREIRA DA SILVA ${ }^{6}$
}

\begin{abstract}
Hancornia speciosa Gomes is a fruit tree native from Brazil that belongs to Apocinaceae family, and is popularly known as Mangabeira. Its fruits are widely consumed raw or processed as fruit jam, juices and ice creams, which have made it a target of intense exploitation. The extractive activities and intense human activity on the environment of natural occurrence of $H$. speciosa has caused genetic erosion in the species and little is known about the ecology or genetic structure of natural populations. The objective of this research was the evaluation of the genetic diversity and genetic structure of $H$. speciosa var. speciosa. The genetic variability was assessed using 11 allozyme loci with a sample of 164 individuals distributed in six natural populations located in the States of Pernambuco and Alagoas, Northeastern Brazil. The results showed a high level of genetic diversity within the species $\left(\hat{H}_{e}=0.36\right)$ seeing that the most of the genetic variability of $H$. speciosa var. speciosa is within its natural populations with low difference among populations $\left(\hat{\theta}_{\mathrm{p}}=0.081\right)$. The inbreeding values within $(\hat{f}=-0.555)$ and among populations $(\hat{F}=-0.428)$ were low showing lacking of endogamy and a surplus of heterozygotes. The estimated gene flow $\left(\hat{N}_{m}\right)$ was high, ranging from 2.20 to 13.18 , indicating to be enough to prevent the effects of genetic drift and genetic differentiation among populations. The multivariate analyses indicated that there is a relationship between genetic and geographical distances, which was confirmed by a spatial pattern analysis using Mantel test $(\mathrm{r}=$ $0.3598 ; \mathrm{p}=0.0920$ ) with 1000 random permutations. The high genetic diversity index in these populations indicates potential for in situ genetic conservation.
\end{abstract}

Index terms: Conservation, gene flow, genetic resources, genetic variability, isozyme, mangabeira.

\section{DIVERSIDADE E ESTRUTURA GENÉTICA EM POPULAÇÕES NATURAIS DE Hancornia speciosa var. speciosa GOMES NO NORDESTE DO BRASIL}

RESUMO - Hancornia speciosa Gomes é uma árvore frutífera nativa do Brasil, pertencente à família Apocinaceae, e é conhecida popularmente como Mangabeira. Seus frutos são amplamente consumidos in natura ou processados como sucos, sorvetes e geleias. $\mathrm{O}$ extrativismo e a intensa atividade antrópica no ambiente de ocorrência natural da Mangabeira, no Nordeste do Brasil, têm causado erosão genética na espécie e pouco se conhece sobre a estrutura genética das populações desta espécie. O objetivo deste trabalho foi avaliar a diversidade e a estrutura genética de populações naturais de H. speciosa var. speciosa. Utilizando 11 locos isoenzimáticos, avaliaram-se 164 indivíduos, amostrados em seis populações naturais localizadas nos Estados de Pernambuco e Alagoas, Nordeste do Brasil. Os resultados mostraram um alto nível de diversidade genética dentro da espécie $\left(H_{e}=0,36\right)$, sendo verificado que a maior parte da variabilidade genética se encontra dentro das populações, com pequena diferenciação entre as mesmas $\left(\theta_{\mathrm{p}}=0,081\right)$. A endogamia dentro das populações $(\hat{f}=-0,555)$ e entre elas $(\hat{F}=-0,428)$ foi baixa, evidenciando ausência de endogamia e excesso de heterozigotos. O fluxo gênico estimado $\left(\hat{N}_{m}\right)$ foi elevado, variando de 2,20 a 13,18 , valores considerados suficientes para evitar os efeitos da deriva genética e a diferenciação genética entre as populações. As análises multivariadas indicam que há relação entre distância genética e espaço geográfico, hipótese esta que foi confirmada por uma análise de padrão espacial,utilizando o teste de Mantel $(\mathrm{r}=0,3598$; $\mathrm{p}=0,0920)$ com 1.000 permutações aleatórias. $\mathrm{O}$ alto índice de diversidade genética nas populações indica potencial para a conservação genética in situ.

Termos para indexação: Conservação de recursos genéticos, fluxo gênico, variabilidade genética, isoenzimas, Mangabeira.

\footnotetext{
1(Trabalho 078-12). Recebido em: 31-01-2012. Aceito para publicação em: 10-08-2012.

${ }^{2}$ M.Sc. in Plant Breeding, Universidade Federal Rural de Pernambuco (UFRPE), CEP 52171-900 Dois Irmãos, Recife-PE. E-mail: georgiavillela_@hotmail.com

${ }^{3}$ Dr. Professor, Department of Biology, Universidade Federal Rural de Pernambuco (UFRPE), CEP 52171-900. Dois Irmãos, Recife-PE. E-mail: luiza@db.ufrpe.br

${ }^{4}$ Dr. Professor, Department of Genetics, Escola Superior de Agricultura “Luiz de Queiroz”, Universidade de São Paulo, C.P. 83, CEP 13418-900 Piracicaba-SP. E-mail: eaveasey@usp.br

${ }^{5} \mathrm{PhD}$ researcher, sponsored by CNPq, Embrapa/IPA, Caixa Postal 1022, CEP:50761-000 Bongi, Recife-PE. E-mail: ildo@ipa.br

${ }^{6}$ Dr. Professor, Department of Biology, Universidade Federal Rural de Pernambuco (UFRPE), CEP 52171-900 Dois Irmãos, Recife-

-PE. E-mail: edson@db.ufrpe.br
} 


\section{INTRODUCTION}

The Mangabeira (Hancornia speciosa Gomes) is a native fruit tree of Brazil, from the Apocinaceae family, occurring spontaneously in the Midwest, Northeast and Southeast, and has a greater abundance in areas of coastal tablelands and coastal lowlands of the Northeast (LEDERMAN et al., 2000). The fruits are fleshy berries very appreciated on juice and ice-cream (LEDERMAN et al., 2000; PEREIRA et al., 2006).

Six varieties have been described in the H. speciosa species: var. speciosa Gomes, var. maximiliani A. DC., var. cuyabensis Malme, var. lundii A. DC., var. gardneri (A.DC.) Muell. Arg., var. pubescens (Nees. Et. Martius) Muell. Arg. (MONACHINO, 1945). Those varieties grow in the Restinga vegetation of Cerrado and Coastal Plain (VIEIRA NETO et al., 2009). According to Ganga et al. (2010) in Northeast occurs the H. speciosa var. speciosa.

Mangabeira is an evergreen tree of medium size that grow up on poor and gravely soil. There is a great vegetative development during the period of higher temperature and the ideal pluviometric index is from 750 to $1.600 \mathrm{~mm}$ per year. This specie is typically allogamous, there are hermaphrodite and self-incompatible flowers and flowering period occur from August to November, with a peak in October (PEREIRA et al., 2006). Insects of the families Euglossinae, Hesperiidae, Urbaninae, Nymphalidae and Sphingidae were observed as pollinators of mangabeira in a study conducted in the State of Paraiba (Darrault; Schlindwein, 2005).

Economically, the Mangabeira has been highlighted because their fruits contain excellent organoleptic characteristics and high nutritional value compared with most of other fruits. Therefore, it has been very much consumed, especially in the Northeast and Midwest regions in Brazil. Its fruits have widespread agribusiness value in those regions, especially for the manufacture of juice and ice cream, and can also be used to produce sweet, syrup, jellies, wine and vinegar (LEDERMAN et al., 2000; VIEIRA NETO, 2002).

According to the Brazilian Institute of Geography and Data Statistics (IBGE, 2011), the Northeast of Brazil is the largest producer of fruits of H. speciosa. In 2010, its production totaled 695 million tons in Northeast while the Southeast's production was 4 tons. Sergipe was the largest producer with $56 \%$ of total production in the region, followed by the states of Bahia and Paraíba.

However, the increase in land speculation and the establishment of monocultures such as coconut, sugar cane and pasture, for instance, on Northeast has caused reduction of native vegetation and caused genetic erosion in populations of $H$. speciosa, especially in the coastal tableland and coastal lowlands (SILVA JÚNIOR et al., 2006, VIEIRA NETO et al., 2009). The exploration performed through the extractivism has also contributed to the degradation of these environments (SILVA JÚNIOR et al., 2006).

The conservation of the species in their natural habitats requires knowledge of the genetic structure and variability within and among populations (BROWN; MORAN, 1981). To access the genetic variability of natural populations of plants, genetic markers can be used to obtain primordial information in order to implement a successful conservation or a breeding program (KARP et al., 1997). Studies based on the polymorphism of genetic markers allow investigations on genetic structure and genetic variability but also could be used to estimate gene flow between populations (SHAW; ALLARD, 1981; HAMRICK, 1982). This methodology was used in studies of natural populations of several fruit species, such as Sirigueleira (Spondias lutea L.) by Gois et al. (2009), Araticunzeiro (Annona crassiflora Mart.) by Telles et al. (2003), Pequizeiro (Caryocar brasiliense Camb.) by Melo Júnior et al. (2004) and Cajá tree (Spondias mombim L.) Silva et al. (2009), for instance.

The information generated in studies of genetic structure and genetic diversity provide important parameters that facilitate the definition of conservation strategies, in order to ensure continuity of the evolutionary process of the species through times (RAO; HODGKIM, 2002). The objective of this research was the study and the knowledge of the genetic diversity and structure of six natural populations of $H$. speciosa var. speciosa in the States of Pernambuco and Alagoas using isozyme markers in order to obtain information that could be used for preservation and in future plant breeding programs.

\section{MATERIALS AND METHODS}

Six natural populations of $H$. speciosa var. speciosa located in the coastal region of the States of Pernambuco and in the Northeastern of Alagoas, corresponding to coastal tablelands and coastal lowlands, were studied (Figure 1). The populations, named Gambá, Itamaracá, Nazaré, Sirinhaém, Tamandaré and Maragogi, were of different sizes: 107, 345, 34, 111, 35 and 225 hectares, respectively, estimated by Global Position System (GPS). 
Twenty four to 30 adult trees were sampled in each population and the samples consisted of young leaves which were collected, placed in plastic bags, kept in ice cooler and carried to the Genetic Laboratory of the Biology Department of the Universidade Federal Rural de Pernambuco, where they were stored at $-80^{\circ} \mathrm{C}$. Population samples were made in order to provide the representation of each population according to the plants density. Each tree was identified by a numbered aluminum plate and georeferenced using GPS (Table 1). The enzymes were extracted from every sample in $1 \mathrm{~mL}$ of extraction buffer $n^{\circ} 1$ (ALFENAS, 1998), with modifications by Martins et al. (2009). The isozymes were separated by horizontal electrophoresis on $13 \%$ starch gel (Penetrose 30). The gel/electrode buffer systems used were TCB (Tris Citrate Borate, $\mathrm{pH}$ 7.5), and LB (Lithium Borate, $\mathrm{pH} 8.5$ ). A total of 16 enzyme systems were initially tested and, out of them, seven were selected for detailed examination because they presented loci and alleles with resolutions that facilitated interpretation: Acid phosphatase (ACP, 3.1.3.2), Alkaline phosphatase (AKP, 3.1.3.1), Esterase (EST, 3.1.1.1), Leucine aminopeptidase (LAP, 3.4.11.1), Malate dehydrogenase (MDH, 1.1.1.37), Superoxide dismutase (SOD, 1.15.1.1) and Glutamate oxaloacetate transaminase (GOT, 2.6.1.1). The interpretations of each enzymatic system were performed according to techniques described in detail in the literature (ALFENAS, 1998).

Genetic diversity parameters such as observed heterozigosity $\left(\hat{H}_{o}\right)$, expected heterozygosity $\left(\hat{H}_{e}\right)$, which corresponds to gene diversity, the percentage of polymorphic loci $(\hat{P})$, the average number of alleles per locus $(\hat{A})$ and estimate of fixation index $\hat{f}=1$ $\left(\hat{H}_{o} / \hat{H}_{\mathrm{e}}\right)$ were obtained by the GDA program of Lewis and Zaykin (2000). The same program was used to estimate the coancestry coefficient obtained from the decomposition of variance analyzes according to Cockerham (1969) and to verify if the estimates were different from zero using the bootstrap resampling for 10.000 replicates on each locus with interval sterling of $95 \%$ probability.

The effective size which measures the genetic representation of the individuals in the population compared to an ideal panmitic population was estimated by the equation proposed by Vencovsky (1992) for a single adult population, $\hat{N}_{e}=\mathrm{n} / 1+\hat{f}$, where, $\mathrm{n}$ is the number of plants sampled and $\hat{f}$ is the population inbreeding coefficient.

In order to measure the gene flow $\left(\hat{N}_{\mathrm{m}}\right)$, the model proposed by Crow and Aoki (1984) was used indirectly according to the following equation: $\hat{N}_{m}=$ $\left[\left(1 / \mathrm{F}_{\mathrm{st}}\right)-1\right] / 4 \alpha$, where $\alpha=[\mathrm{n} /(\mathrm{n}-1)]^{2}$; and where
$N_{m}=$ number of migrants per generation, $n=$ the numbers of populations and $\mathrm{F}_{\text {st }}$ genetic divergence among populations, which was calculated by the combinations of pairs of populations, also using the GDA program.

The clustering of populations, constructed by the UPGMA method and Nei (1978) genetic distances, and the Mantel test were performed using the FTPGA computer program, version 1.3 (Tools for Population Genetic Analyses) (MILLER, 1997).

\section{RESULTS AND DISCUSSION}

The seven isoenzyme systems studied allowed the identification of 11 loci (Table 2). The ACP1 presented only one allele, ACP2 and GOT revealed three alleles and the other systems revealed two alleles each, totaling 23 .

There was wide variation in allele frequencies from fixed, as ACP1 in all populations, to absence of alleles, as LAP2 in all populations except Nazaré. Allele 3 for ACP2 was found only in Maragogi and Nazare populations and with low frequencies (0.007 and 0.096, respectively), therefore, it was classified as a rare allele. Allele 2 for LAP2 was exclusive because it was only observed in the Nazaré population (Table 2). No alleles were observed in Sirinhaém population for EST2 loci. Allele 3 was not observed for GOT in Tamandaré and Maragogi populations, whereas in other populations its frequency was very low, except in Nazaré population, and therefore, it may also be considered a rare allele $(p<0,05)$ (VIEGAS, et al. 2011).

Normally changes in allele frequencies between populations is indicative of genetic drift or also be due to the exchange of alleles through migration processes. Analysis of allele frequencies are of great importance because it reflects the stochastic effects more suitable than most of the parameters studied in genetic population (BOTREL; CARVALHO, 2004).

For the 11 loci studied, the percentage of polymorphic loci $(\hat{P})$ ranged from $73 \%$ (Tamandaré) to $91 \%$ (Nazaré) (Table 3). Lower values were found by Botrel et al. (2006) studying Jacareúba (Calophyllum brasiliense) (37.5 and 50\%) and higher or similar values were found in populations of other native species, with reproduction typically alogamous, such as in Siriguela (Spondias lutea L.) (GOIS et al., 2009) presenting 90\% polymorphic loci, Cajá tree (Spondias monbim) (SILVA et al., 2009) and Faveiro (Dimorphandra mollis) (GONÇALVES et al., 2010), for instance. The average number of allele per locus $(\hat{A})$ among populations ranged 
from 1.82 to 2.09 (Table 3). Hamrick and Godt (1990) gathered in a review, results of 653 studies with isozymes and estimated for plant species, on average, $50.5 \%$ of polymorphic loci and 1.96 alleles per locus. Therefore, considering the isozymes systems used, the populations of Mangabeira studied showed good levels of polymorphism, which makes it favorable for in situ genetic conservation with the purpose of the species preservation as much genetic variability as possible.

In this research all populations showed high average observed heterozygosity $\left(\hat{H}_{o}\right)$, ranging from 0.51 to 0.64 among populations and the expected heterozygosity $\left(\hat{H}_{e}\right)$, which corresponds to gene diversity, varied from 0.30 to 0.42 , also considered high for natural populations (Table 3). Although all populations showed high levels of diversity, a strong high human pressure was observed among them, seeing that it was more evident at Gambá and Sirinhahém populations. However, the lower diversity was observed at Tamandaré population $\left(\hat{H}_{e}=0.30\right)$.

High heterozygosity has been observed in many natural populations of tropical fruits (MELO JÚNIOR et al., 2004) $\hat{H}_{e}$ ranged from 0.450 and 0.530, (GOIS et al., 2009) $\hat{H}_{e}=0.514$; (SILVA et al., 2009) $\hat{H}_{e}$ ranged from 0.530 to 0.574 and (GONÇALVES et al., 2010), $\hat{H}_{e}=0.463$. According to Sebbenn et al. (2000), high levels of heterozygosity are extremely important because it makes possible the occurrence of a large number of new genotypic combinations, increasing the evolutionary potential of species, and the ability to adapt to any environmental changes.

The fixation indices $(\hat{f})$ were negative for all population, ranging from -0.69 in Tamandaré population to - 0.44 in Gambá population (Table 3). Considering average indices for allele fixation for each population $(\hat{f})$ the values were also negative, ranging from -0.788 for LAP1 to -0.137 for LAP2 and not found for ACP1. Among populations the allele fixation $(\hat{F})$ ranged from -0.724 to -0.020 , LAP1 and LAP2, respectively (Table 4). Negative values for fixation indexes indicate inbreeding absence in the population, confirming the high heterozygosity found and suggesting that these populations are panmictics.

The genetic divergence among populations for all isozyme loci and the average value $\left(\hat{\theta}_{p} 0.081\right)$ were considered low, but high if compared to other most tropical tree species, which are less than 0.05 or 5\% (BOTREL et al., 2006; MELO JÚNIOR et al.; 2004; SILVA et al., 2009). Therefore, the largest part of genetic variability found in this study is due to within populations variability $92 \%$ (1- 0.081) according to Table 4 .

The effective population size $\left(\hat{N}_{e}\right)$ values, which correspond to the genetic representation of the samples, reaffirm the existence of low inbreeding in the populations studied, considering that the effective sizes calculated for each population was higher than the number of individuals sampled (Table 3 ). That parameter is important in order to evaluate the impact of genetic drift on the structure of populations and essential for the in situ genetic conservation (MORAES; DERBYSHIRE, 2002). The relationship between the size and effective population size $\left(\hat{\mathrm{N}}_{\mathrm{e}} / \mathrm{n}\right.$ allows to the calculation of minimum value for a viable population size, which corresponds to the number of individuals needed for the population to maintain their genetic integrity. According to Raposo et al. (2007), this relationship is also fundamental to the establishment of conservation strategies.

The estimated gene flow $\left(\hat{N}_{m}\right)$ for each populations combination varied from 2.20 (Sirinhaém and Maragogi) to 13.18 (Gambá and Itamaracá) (Table 5). For all populations' combination, $\hat{N}_{m}$ indices were higher than 1.0, showing that alleles are exchanged with high frequency among populations, avoiding the genetic differentiations (ELLTSRAD, 2003; SLATKIN; BARTON, 1989).

The values obtained for $\hat{N}_{m}$ agrees with the low value of genetic differentiation among populations $\left(\hat{\theta}_{p}=0.081\right)$. Other studies carried out with several native fruits such as Pequi ( $C$. brasiliense) by Melo Júnior et al. (2004) and Cajá tree (S. mombim) by Silva et al. (2009), for instance, also showed high values of gene flow (15.56) and (10.35), respectively. The maintenance $N_{m}$ of values higher than 1.0 is a factor that minimizes genetic drift effect and avoids or retards the genetic differentiation between populations.

The genetic identity (GI) shows that the six populations are very similar, ranging from $0.99 \%$ to $0.93 \%$, and agrees with the low $F_{S T}$ values (Table 5). For some population combinations, mainly with Maragogi population, the larger geographic distances did not correspond with the smaller gene flow $\left(\hat{N}_{m}\right)$ values, probably because the gene flow is a historic parameter and the separation of the populations could have occurred on different times, principally by human action. Another possibility is that Maragogi population is one of the most affected by human impact, as urbane improves, which have caused genetic drift.

The pattern of genetic divergence among the six populations of $H$. speciosa var. speciosa can be viewed on the genetic distance dendrogram obtained 
by UPGMA method (Figure 2). Although the low level of divergence among populations, it suggests the existence of three clusters forming a hierarchical pattern, with Gambá, Itamaracá and Nazaré, Sirinhaém and Tamandaré in a second cluster, and Maragogi in a separated from the others. Gambá and Itamaracá show higher geographical distances from the populations of the other two clusters, which may support their isolation by distance.

The Mantel test showed a positive correlation $(\mathrm{r}=0.3598$ and $\mathrm{p}=0.0920)$ between genetic $\left(F_{S T}\right)$ and geographic distances (Figure 3). The distribution pattern was similar to that formed by UPGMA clustering, with the formation of three groups. Despite the relatively low density of the correlation between two matrices, compared to other species such as Cagaiteira (Eugenia dysenterica) (TELLES et al., 2001) which showed $\mathrm{r}=0.72$ and Pau-papel (Tibouchina papyrus) (TELLES et al., 2010) with $\mathrm{r}$ $=0.71$, the correlation between the six populations of $H$. speciosa var. speciosa has indicated that the genetic and geographic distances are related.

TABLE 1 - Collection site and number of individuals sampled (n) of six populations of Hancornia speciosa var. speciosa Gomes and their geographical coordinates.

\begin{tabular}{|c|c|c|c|c|}
\hline \multirow{2}{*}{ Population } & \multirow{2}{*}{ Location } & \multirow{2}{*}{$\mathbf{n}$} & \multicolumn{2}{|c|}{ Geographical coordinates } \\
\hline & & & Latitude & Longitude \\
\hline Gambá & Goiana (PE) & 24 & $07^{\circ} 40^{\prime} 14^{\prime \prime}$ & $43^{\circ} 54^{\prime} 42^{\prime \prime}$ \\
\hline Itamaracá & Itamaracá (PE) & 28 & $07^{\circ} 43^{\prime} 10^{\prime \prime}$ & $34^{\circ} 50^{\prime} 33^{\prime \prime}$ \\
\hline Nazaré & $\begin{array}{c}\text { Cabo de St. } \\
\text { Agostinho (PE) }\end{array}$ & 26 & $08^{\circ} 20^{\prime} 45^{\prime \prime}$ & $34^{\circ} 57^{\prime} 25^{\prime \prime}$ \\
\hline Sirinhaém & Sirinhaém (PE) & 28 & $08^{\circ} 40^{\prime} 49^{\prime \prime}$ & $35^{\circ} 05^{\prime} 09^{\prime \prime}$ \\
\hline Tamandaré & Tamandaré (PE) & 30 & $08^{\circ} 44^{\prime} 42^{\prime \prime}$ & $35^{\circ} 05^{\prime} 46^{\prime \prime}$ \\
\hline Maragogi & Maragogi (AL) & 26 & $08^{\circ} 32^{\prime} 12^{\prime \prime}$ & $35^{\circ} 19^{\prime} 12^{\prime \prime}$ \\
\hline
\end{tabular}

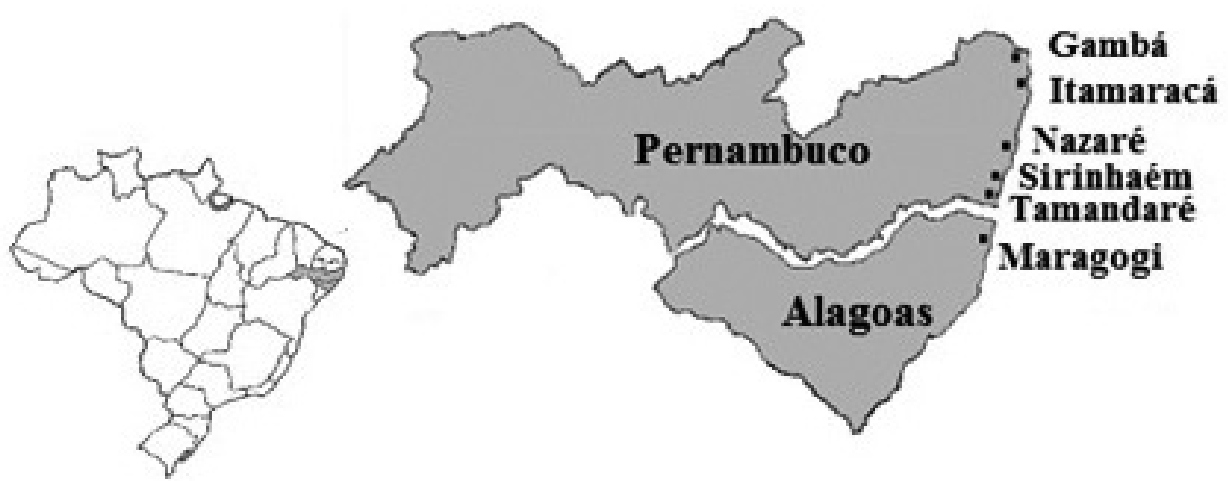

FIGURE 1 - Brazilian map with detail of the states Pernambuco and Alagoas showing the distribution of six sampled populations of Hancornia speciosa var. speciosa Gomes. 
TABLE 2 - Frequency of alleles observed at each locus in six Hancornia speciosa var. speciosa Gomes populations studied: Gambá (Gam), Itamaracá (Ita), Nazaré (Naz), Sirinhaém (Sir) Tamandaré (Tam) and Maragogi (Mar).

\begin{tabular}{cccccccc}
\hline \multirow{2}{*}{ Locus } & Alleles & \multicolumn{7}{c}{ Populations } \\
\cline { 3 - 8 } & & Gam & Ita & Naz & Sir & Tam & Mar \\
\hline ACP1 & 1 & 1.000 & 1.000 & 1.000 & 1.000 & 1.000 & 1.000 \\
& 1 & 0.521 & 0.370 & 0.536 & 0.357 & 0.500 & 0.577 \\
ACP2 & 2 & 0.497 & 0.630 & 0.393 & 0.643 & 0.500 & 0.327 \\
& 3 & 0.000 & 0.000 & 0.007 & 0.000 & 0.000 & 0.096 \\
& 1 & 0.652 & 0.981 & 0.500 & 0.571 & 0.583 & 0.942 \\
AKP & 2 & 0.348 & 0.019 & 0.500 & 0.429 & 0.417 & 0.058 \\
& 1 & 0.625 & 0.625 & 0.542 & 0.893 & 1.000 & 0.500 \\
EST1 & 2 & 0.375 & 0.375 & 0.458 & 0.107 & 0.000 & 0.500 \\
& 1 & 0.647 & 0.675 & 0.525 & $* \mathrm{NA}$ & 0.367 & 0.500 \\
EST2 & 2 & 0.353 & 0.325 & 0.475 & $* \mathrm{NA}$ & 0.633 & 0.500 \\
& 1 & 0.750 & 0.630 & 0.607 & 0.500 & 0.500 & 0.750 \\
LAP1 & 2 & 0.250 & 0.370 & 0.393 & 0.500 & 0.500 & 0.250 \\
& 1 & 1.000 & 1.000 & 0.857 & 1.000 & 1.000 & 1.000 \\
LAP2 & 2 & 0.000 & 0.000 & 0.143 & 0.000 & 0.000 & 0.000 \\
& 1 & 0.833 & 0.750 & 0.696 & 0.839 & 0.981 & 0.442 \\
MDH1 & 2 & 0.167 & 0.250 & 0.304 & 0.161 & 0.019 & 0.558 \\
& 1 & 0.684 & 0.640 & 0.796 & 0.813 & 0.942 & 0.947 \\
MDH2 & 2 & 0.316 & 0.360 & 0.204 & 0.188 & 0.058 & 0.053 \\
& 1 & 0.646 & 0.685 & 0.661 & 0.696 & 0.567 & 0.577 \\
SOD & 2 & 0.354 & 0.315 & 0.339 & 0.304 & 0.433 & 0.423 \\
& 1 & 0.604 & 0.571 & 0.630 & 0.574 & 0.667 & 0.596 \\
GOT & 2 & 0.333 & 0.393 & 0.296 & 0.259 & 0.333 & 0.404 \\
& 3 & 0.063 & 0.036 & 0.074 & 0.167 & 0.000 & 0.000 \\
\hline
\end{tabular}

*NA $=$ not found.

TABLE 3 - Indices of genetic diversity in Hancornia speciosa var. speciosa Gomes populations based on 11 allozyme loci.

\begin{tabular}{ccccccccc}
\hline Population & $\mathbf{n}$ & $\hat{\boldsymbol{P}}$ & $\hat{\boldsymbol{A}}$ & $\hat{\boldsymbol{H}}_{o}$ & $\hat{\boldsymbol{H}}_{e}$ & $\hat{\boldsymbol{f}}$ & $\hat{\boldsymbol{N}}_{e}$ & $\hat{\boldsymbol{N}}_{\boldsymbol{e}} / \boldsymbol{n}$ \\
\hline Gambá & 24 & 0.81 & 1.91 & 0.52 & 0.37 & -0.44 & 42.9 & 1.79 \\
Itamaracá & 28 & 0.82 & 1.91 & 0.51 & 0.34 & -0.52 & 58.3 & 2.08 \\
Nazaré & 26 & 0.91 & 2.09 & 0.64 & 0.42 & -0.60 & 65.0 & 2.50 \\
Sirinhaém & 28 & 0.82 & 1.90 & 0.52 & 0.39 & -0.54 & 60.9 & 2.17 \\
Tamandaré & 30 & 0.73 & 1.82 & 0.46 & 0.30 & -0.69 & 96.8 & 3.23 \\
Maragogi & 26 & 0.82 & 1.90 & 0.51 & 0.35 & -0.57 & 60.5 & 2.33 \\
\hline Mean & $\mathbf{2 7}$ & $\mathbf{0 . 8 2}$ & $\mathbf{1 . 9 2}$ & $\mathbf{0 . 5 3}$ & $\mathbf{0 . 3 6}$ & $\mathbf{- 0 . 5 6}$ & $\mathbf{6 4 . 0}$ & $\mathbf{2 . 3 5}$ \\
\hline
\end{tabular}

Percentage of polymorphic loci $(\hat{P})$, average number of alleles per locus $(\hat{A})$, observed $\left(\hat{H}_{o}\right)$ and expected $\left(H_{e}\right)$ heterozygosities, fixation index $(f)$, effective population sizes $\left(\hat{\mathrm{N}}_{\mathrm{e}}\right)$ and relationship between the effective population size and actual size $\left(\hat{\mathrm{N}}_{\mathrm{e}} / \mathrm{n}\right)$. 
TABLE 4 - Coefficient of coancestrality evaluated for 11 allozyme loci studied in six natural Hancornia speciosa var. speciosa Gomes populations.

\begin{tabular}{cccc}
\hline Locus & $\hat{f}$ & $\hat{F}$ & $\hat{\theta}_{p}$ \\
\hline ACP1 & Un. & Un. & Un. \\
ACP2 & -0.623 & -0.544 & 0.048 \\
AKP & -0.729 & -0.387 & 0.197 \\
EST1 & -0.688 & -0.365 & 0.191 \\
EST2 & -0.597 & -0.507 & 0.057 \\
LAP1 & -0.788 & -0.724 & 0.036 \\
LAP2 & -0.137 & -0.020 & 0.103 \\
MDH1 & -0.300 & -0.086 & 0.265 \\
MDH2 & -0.231 & -0.134 & 0.079 \\
SOD & -0.432 & -0.426 & 0.004 \\
GOT & -0.532 & -0.520 & 0.008 \\
\hline Mean & $\mathbf{- 0 . 5 5 5}$ & $\mathbf{- 0 . 4 2 8}$ & $\mathbf{0 . 0 8 1}$ \\
\hline
\end{tabular}

Inbreeding within populations $(\hat{f})$, inbreeding among populations $(\hat{F})$ and genetic divergence among populations $\left(\hat{\theta}_{p}\right)$, Un $=$ not significant undefined value.

TABLE 5 - Genetic identity $(G I)$, estimated genetic differentiation $\left(F_{S T}\right)$ average Nei's (1978), gene flow $\left(\hat{\mathrm{N}}_{\mathrm{m}}\right)$ and physical distance at the combined Hancornia speciosa var. speciosa Gomes populations.

\begin{tabular}{ccccc}
\hline Combinations & $G I$ & $F_{s t}$ & $\begin{array}{c}\text { Physical } \\
\text { distance } \\
\text { (Km) }\end{array}$ & $\hat{\mathrm{N}}_{\mathrm{m}}$ \\
\hline Gam x Ita & 0.98 & 0.013 & 9.4 & 13.18 \\
Gam x Naz & 0.99 & 0.018 & 74.8 & 9.47 \\
Gam x Sir & 0.98 & 0.030 & 113.3 & 5.61 \\
Gam x Tam & 0.96 & 0.040 & 120.6 & 4.17 \\
Gam x Mar & 0.95 & 0.061 & 152.2 & 2.67 \\
Ita x Naz & 0.96 & 0.037 & 70.4 & 4.52 \\
Ita x Sir & 0.96 & 0.037 & 109.6 & 4.52 \\
Ita x Tam & 0.93 & 0.061 & 116.8 & 2.67 \\
Ita x Mar & 0.96 & 0.056 & 148.9 & 2.93 \\
Naz x Sir & 0.97 & 0.035 & 39.7 & 4.79 \\
Naz x Tam & 0.96 & 0.040 & 46.8 & 4.17 \\
Naz x Mar & 0.96 & 0.036 & 79.2 & 4.68 \\
Sir x Tam & 0.99 & 0.020 & 7.2 & 8.50 \\
Sir x Mar & 0.93 & 0.073 & 39.6 & 2.20 \\
Tam x Mar & 0.99 & 0.063 & 32.6 & 2.58 \\
\hline
\end{tabular}




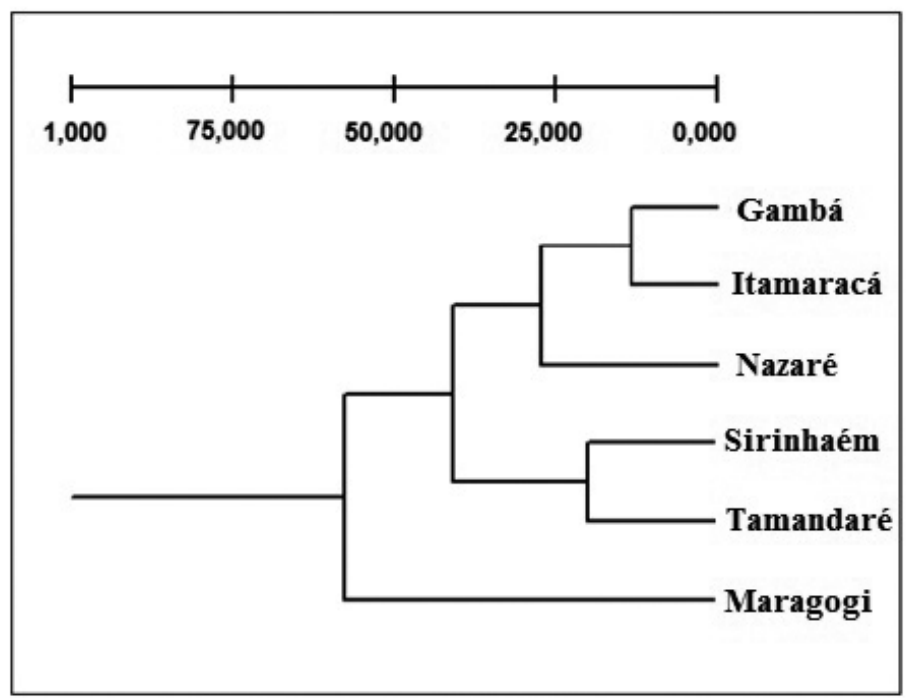

FIGURE 2 - Cluster analysis of Nei's genetic distances and UPGMA method between the six Hancornia speciosa var. speciosa Gomes populations studied.

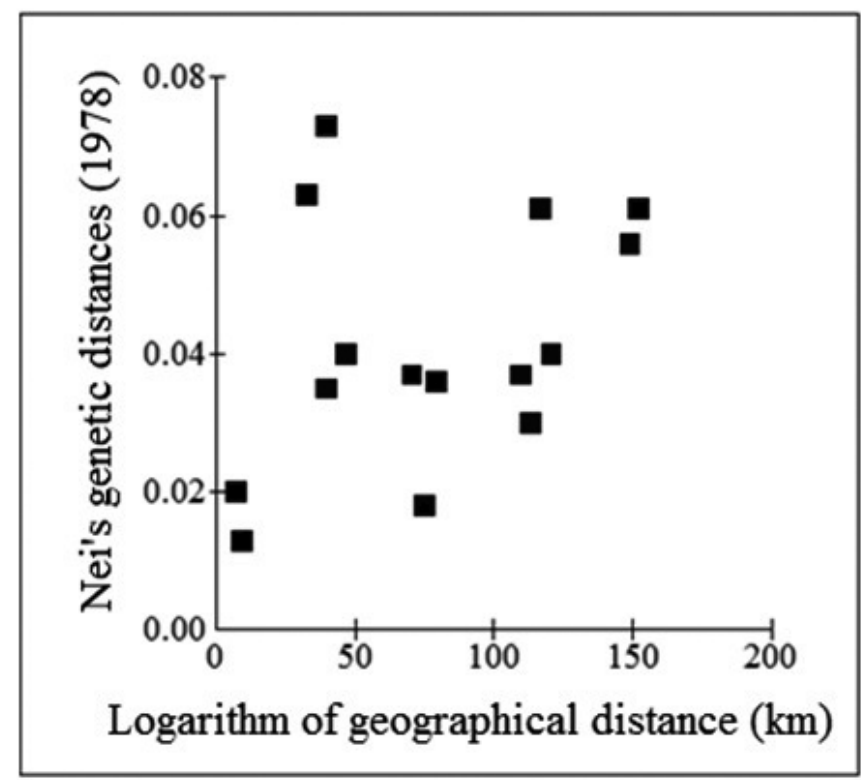

FIGURE 3 - Non-biased genetic relationship of Nei (1978) and geographical distances among the six Hancornia speciosa var. speciosa Gomes populations studied. The Mantel correlation coefficient was $\mathrm{r}=0.3598 ; \mathrm{p}=0.0920$. 


\section{CONCLUSIONS}

1- The populations of H. speciosa var. speciosa studied showed high levels of genetic diversity, most of which is found within populations.

2- The low fixation index observed in six populations, shows the absence of inbreeding, and represents a typical result of an allogamous species.

3- Although the low genetic divergence, there is a spatial pattern for these populations, suggesting a small degree of genetic drift.

4- Nazaré population, which showed higher levels of diversity, would be more suitable for in situ conservation.

\section{ACKNOWLEDGEMENTS}

The authors would like to thank $\mathrm{CNPq}$ for financially supporting the project and the Company Corn Products Brazil (Pernambuco unit), for giving cornstarch (penetrose) used in the preparation of gels for electrophoresis.

\section{REFERÊNCIAS}

ALFENAS, A.C. Eletroforese de isoenzimas e proteínas afins: fundamentos e aplicações em plantas e microorganismos. Viçosa: Universidade Federal de Viçosa, 1998. 574p.

BOTREL, M.C.G.; CARVALHO, D. Variabilidade isoenzimática em populações naturais de jacarandá paulista (Machaerium villosum Vog.). Revista Brasileira de Botânica, São Paulo, v.27, p.621-627, 2004.

BOTREL, M.C.G.; SOUZA, A.M.; CARVALHO, D.; PINTO, S.I.C.; MOURA, M.C.O.; ESTOPA, R.A. Caracterização genética de Calophyllum brasiliense Camb. em duas populações de mata ciliar. Revista Árvore, Viçosa, MG, v.33, p.821-827, 2006.

BROWN, A.H.D.; MORAN, G.F. Isozymes and the genetic resources of forest trees. In: CONCKLE, M.T. Isozymes of North American forest insects. Bekeley: Department Agriculture, 1981. p.1-10.

COCKERHAM, C.C. Variance of gene frequencies. Evolution, Lancaster, v.23, p.72-84, 1969.
CROW, J.F.; AOKI, K. Group selection for polygenic behavioral trait: estimating the degree of population subdivision. Proceedings of the Natural Academy of Sciences of the United States of America, Washington, v.81, p.6073-6077, 1984.

DARRAULT, R.O.; SCHLINDWEIN, C. Limited fruit production in Hancornia speciosa (Apocynaceae) and pollination by nocturnal and diurnal insects. Biotropica, Washington, v. 37, p.381-388, 2005.

ELLTSRAD, N.C. Current knowledge of gene flow in plants: implications for transgene flow. Philosophical Transactions of the Royal Society of London, London, v.358, p.1163-1170, 2003.

GANGA, R.M.D.; FERREIRA, G.A.; CHAVES, L.J.; NAVES, R.V.; NASCIMENTO, J.L.do. Caracterização de frutos e árvores de populações naturais de Hancornia speciosa Gomes do Cerrado. Revista Brasileira de Fruticultura, Jaboticabal, v.32, p.101103, 2010.

GOIS, I.B.; SILVA-MANN, R.; FERREIRA, R.A. Variabilidade genética de Spondias lutea L. em uma população do baixo São Francisco sergipano, por meio de isoenzimas. Scientia Forestalis, Piracicaba, v.37, p.55-60, 2009.

GONÇALVES, A.C.; VIEIRA, A.F.; REIS, C.A.F.; CARVALHO, D. Conservação de Dimorphandra mollis Benth. (Fabaceae) baseada na estrutura genética de populações naturais. Revista Árvore, Viçosa, MG, v.34, p.95-101, 2010.

HAMRICK, J.L. Plant population genetics and evolution. American Journal of Botany, Columbus, v.69, p.1685-1693, 1982.

HAMRICK, J.L.; GODT, M.J.W. Allozyme diversity in plant species. In: BROW, A.H.D.; CLEGG, M.T.; KAHLER, A.L.; WEIR, B.S. Plant population genetics, breeding and genetic resources. Sunderland: Sinauer Associates, 1990. p.43-63.

IBGE. Censo agropecuário 2011. Rio de Janeiro, 2011.

KARP, A.; KRESOVICH, S.; BHAT, K.V.; AYADA, W.G.; HODGKIN, T. Molecular tools in plant genetic resources conservation: a guide to the technologies. Rome: International Plant Genetic Resources Institute, 1997. 47p. 
LEDERMAN, I.E; SILVA Jr., J.F.; BEZERRA, J.E.F.; ESPINDOLA, A.C.M. Mangaba (Hancornia speciosa Gomes). Jaboticabal: Funep, 2000. 35p. (Série Frutas Nativas, 2)

LEWIS, P.O.; ZAYKIN, D. Genetic data analysis: computer program for the analysis of allelic data. Version 1.0. 2000. Disponível em: <http://alleyn. eeb.uconn.edu/gda/2000>. Acesso em: 9 nov. 2010.

MARTINS, G.V.; SILVA, E.F.; LEDERMAN, I.E.; SILVA, U.C.; RODRIGUES, D.V.S. Metodologia para extração e eletroforese de isoenzimaspara a mangabeira (Hancornia speciosa Gomes). In: JORNADA DE ENSINO, PESQUISA E EXTENSÃO DA UFRPE, 9., 2009, Recife. Anais... CD-ROM.

MELO JUNIOR, A. F. de; CARVALHO, D. de; PÓVOA, J.S.R. ; BEARZOLI, E. Estrutura genética de populações naturais de pequizeiro (Caryocar brasiliense Camb). Scientia Forestalis, Piracicaba, v.66, p.56-65, 2004.

MILLER, M.P. TFPGA - tools for population genetic analyses: a windows program for the analyses of allozymes and molecular population genetic data. Flagstaff: Department of Biological Sciences, Northern Arizona University, 1997.

MONACHINO, J. A revision of Hancornia (Apocynaceae). Lilloa, Tucumán, v.11, p.19-48, 1945.

MORAES, P.L.R.; DERBYSHIRE, M.T.V.C. Estrutura genética de populações naturais de Cryptocarya aschersoniana Mez (Lauraceae) através de marcadores isoenzimáticos. Biota Neotropica, São Paulo, v.2, n.2, p.1-19, 2002.

NEI, M. Estimation of average heterozygosity and genetic distance from a small number of individuals. Genetics, Bethesda, v.89, n.3, p.583-590, 1978.

PEREIRA, A.V.; PEREIRA, E.B.C.; SILVA JÚNIOR, J.F. da.; SILVA, D.B. da. Mangaba. In: VIEIRA, R. F. (Ed.). Frutas nativas da região Centro-Oeste do Brasil. Brasília: Embrapa Recursos Genéticos e Biotecnologia, 2006. p.186-211.

RAO, R.V.; HODGKIM, T. Genetic diversity and conservation and utilization of genetic resources. Plant Cell, Rockville, v.68, p.1-19, 2002.
RAPOSO, A.; MARTINS, K.; CIAMPI, A.Y.; WADT, L.H.O.; VEASEY, E.A. Diversidade genética de populações de andiroba no Baixo Acre. Pesquisa Agropecuária Brasileira, Brasília, v.42, p.1291-1298, 2007.

SEBBENN, A.M.; KAGEYAMA, P.Y.; SIQUEIRA, A.C.M.F.; ZANATTO, A.C.S. Sistema de cruzamento em populações de Cariniana legalis Mart. O. Ktze.: implicações para a conservação e o melhoramento genético. Scientia Forestalis, Piracicaba, v.58, p.25-40, 2000.

SHAW, D.V.; ALLARD, R.W. Analysis of mating system parameters and population structure in Douglas-fir using single locus and multilocus methods. In: SYMPOSIUM ON ISOZYMES OF NORTH AMERICAN FOREST TREES AND FOREST INSECT, 1981, Berkeley. Proceedings... Berkeley: USDA Forestry General Technical Report, 1981. p.18-22, 1981.

SILVA JUNIOR, J.F da ; ARAUJO, I.A.; BARREIRO NETO, M.; ESPÍNDOLA, A.C.M.; CARVALHO, N.S.G.; MOTA, D.M. Recursos genéticos nos tabuleiros costeiros e baixada litorânea do Nordeste. In: SILVA JUNIOR, J. F. da; LÉDO, A. da S. A cultura da mangaba. Aracaju: Embrapa Tabuleiros Costeiros, 2006. p.57-74.

SILVA, E.F.; MARTINS, L.S.S.; OLIVEIRA, V.R. Diversity and genetic structure in cajá tree (Spondias mombin L.) populations in Northeastern Brazil. Revista Brasileira de Fruticultura, Jaboticabal, v.31, p.117-181, 2009.

SLATKIN, M.; BARTON, N.H. A comparison of three methods for estimating average levels of gene flow. Evolution, Lawrence, v.43, p.1349-1368, 1989.

TELLES, M.P.C.; SILVA, S.P. da, RAMOS, J.R.; SOARES, T.N.; MELO, D.B.; RESENDE, L.V.; BATISTA, E.C.; VASCONCELLOS, B.F. Estrutura genética em populações naturais de Tibouchina papyrus (pau-papel) em áreas de campo rupestre no cerrado. Revista Brasileira de Botânica, São Paulo, v.33, p.291-300, 2010.

TELLES, M.P.C.; SILVA, R.S.M.; CHAVES, L.J.; COELHO, A.S.G.; DINIZ FILHO, J.A.F. Divergência entre subpopulações de cagaiteira (Eugenia dysenterica) em resposta a padrões edáficos e distribuição espacial. Pesquisa Agropecuária Brasileira, Brasília, v.36, p.1387-1394, 2001. 
TELLES, M.P.C.; VALVA, FABRIZIO D.; BANDEIRA, L.F.; COELHO A.S.G.. Caracterização genética de populações naturais de araticunzeiro (Annona crassiflora Mart. - Annonaceae) no Estado de Goiás. Revista Brasileira de Botânica, São Paulo, v.26, p.123-129, 2003.

VENCOVSKY, R. Análise de variância de freqüências alélicas. Revista Brasileira de Genética, Ribeirão Preto, v.15, p.53-60, 1992.

VIEGAS, M.P; SILVA, C.L.S.P; MOREIRA, J.P; CARDIN, L.T; AZEVEDO, V.C.R; CIAMPI, A.Y; FREITAS, M.L.M; MORAES, M.L.T de; SEBBENN, A.M. Diversidade genética e tamanho efetivo de duas populações de Myracrodruon urundeuva Fr. All., sob conservação ex situ. Revista Árvore, Viçosa, MG, v.35, n.4, p.769-779, 2011.
VIEIRA NETO, R.D. Fruteiras tropicais para os tabuleiros costeiros e baixadas litorâneas. Aracajú: Embrapa. 2002. 216p.

VIEIRA NETO, R.D.; MELO, V.S.; DANTAS, J.O. Caracterização do sistema produtivo da mangabeira no Município de Itaporanga D'Ajuda. Aracajú: Embrapa Tabuleiros Costeiros, 2009. 21p. (Boletim de Pesquisa e Desenvolvimento) 